Maps and the Writing of Space in Early Modern England and Ireland 
This page intentionally left blank 


\section{Maps and the Writing of Space in Early Modern England and Ireland}

Bernhard Klein

Lecturer in English

University of Dortmund

Germany 


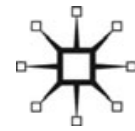

(C) Bernhard Klein 2001

Softcover reprint of the hardcover 1st edition 2001 978-0-333-77933-0

All rights reserved. No reproduction, copy or transmission of this publication may be made without written permission.

No paragraph of this publication may be reproduced, copied or transmitted save with written permission or in accordance with the provisions of the Copyright, Designs and Patents Act 1988, or under the terms of any licence permitting limited copying issued by the Copyright Licensing Agency, 90 Tottenham Court Road, London W1T 4LP.

Any person who does any unauthorised act in relation to this publication may be liable to criminal prosecution and civil claims for damages.

The author has asserted his right to be identified as the author of this work in accordance with the Copyright, Designs and Patents Act 1988.

Published by

PALCRAVE MACMILLAN

Houndmills, Basingstoke, Hampshire RG21 6XS and

175 Fifth Avenue, New York, N.Y. 10010

Companies and representatives throughout the world

PALCRAVE MACMILLAN is the global academic imprint of the Palgrave Macmillan division of St. Martin's Press, LLC and of Palgrave Macmillan Ltd. Macmillan ${ }^{\circledR}$ is a registered trademark in the United States, United Kingdom and other countries. Palgrave is a registered trademark in the European Union and other countries.

ISBN 978-1-349-41831-2 ISBN 978-0-230-59811-9 (eBook) DOI 10.1057/9780230598119

This book is printed on paper suitable for recycling and made from fully managed and sustained forest sources. Logging, pulping and manufacturing processes are expected to conform to the environmental regulations of the country of origin.

A catalogue record for this book is available from the British Library.

Library of Congress Catalog Card Number: 00-033348 
To the memory of my father Heinz Werner Klein 1927-1980 
This page intentionally left blank 


\section{Contents}

List of Figures viii

List of Plates ix

Acknowledgements - xi

Introduction: The Cartographic Transaction 1

$\begin{array}{lc}\text { Part I Measurements } & 13\end{array}$

$\begin{array}{ll}\text { Introduction } & 15\end{array}$

1 Mathematics of the World 21

2 Land Measuring: an Upstart Art 42

3 Surveying Ireland $\quad 61$

$\begin{array}{ll}\text { Part II Cartographies } & 77\end{array}$

$\begin{array}{ll}\text { Introduction } & 79\end{array}$

4 The Whole World at One View $\quad 85$

5 Mapping the Nation 97

6 The Image of Ireland 112

$\begin{array}{ll}\text { Part III Narratives } & 131\end{array}$

$\begin{array}{ll}\text { Introduction } & 133\end{array}$

7 Imaginary Journeys: Describing Britain 137

8 The Poetics of National Space 149

9 Groundless Fictions: Writing Irish Space 171

$\begin{array}{lr}\text { Notes } & 188\end{array}$

$\begin{array}{ll}\text { Index } & 225\end{array}$ 


\section{List of Figures}

1.1 Hartmann Schedel: imaginary view of Marseille, Trier and Nice (1493). Stadt- und Universitätsbibliothek Frankfurt am Main. (HB 22 Dk 411.)

1.2 Hartmann Schedel: heads and houses (1493). Stadt- und Universitätsbiliothek Frankfurt am Main. (HB 22 Dk 411.)

1.3 Peter Apian: the difference between geography and chorography (1524). Senckenbergische Bibliothek Frankfurt am Main. (P.351.8782/1.)

1.4 Sebastian Münster: thumbnail sketch of Britain and Ireland (1544). Stadt- und Universitätsbibliothek Frankfurt am Main. (Wf 297.)

1.5 Sebastian Münster: view of Trier (1550). Stadt- und Universitätsbibliothek Frankfurt am Main. (Wf 297.)

1.6 Sebastian Münster: map of feminized Europe (1588). Stadtund Universitätsbibliothek Frankfurt am Main. (Wf 297.)

1.7 Sebastian Münster: map of Europe based on Ortelius (1588). Stadt- und Universitätsbibliothek Frankfurt am Main. (Wf 297.)

2.1 Aaron Rathborne: frontispiece of The Surveyor (1616). By permission of the British Library. (528.n.20.)

2.2 Leonard Digges: title-page of Tectonicon (first published in 1556). By permission of the British Library. (8504.c.20.)

2.3 Cyprian Lucar: the arsenal of the plane table man (1590). By permission of the British Library. (C.114.e.4.)

2.4 William Leybourn: a model estate map (1654). By permission of the British Library. (530.m.5.)

8.1 Michael Drayton: introductory map to song 15, containing the river marriage (1612). By permission of the British Library. (C.116.g.2.) 


\section{List of Plates}

1 Johann Vermeer, The Geographer (1668). Städelsches Kunstinstitut Frankfurt am Main.

2 Abraham Ortelius: map of Africa (1570). Stadt- und Universitätsbibliothek Frankfurt am Main. (Wf 127.)

3 Abraham Ortelius: map of the world (1570). Stadt- und Universitätsbibliothek Frankfurt am Main. (Wf 127.)

4 John Speed, The Kingdome of Great Britaine and Ireland (1611). By permission of the British Library. (Maps C.7.c.20.)

5 Laurence Nowell, General Description of England and Ireland (1564/5). By permission of the British Library. (Add Ms 62540.)

6 Christopher Saxton, Anglia (1579). By permission of the British Library. (Maps C.7.c.1.)

7 John Speed, Kingdome of England (1611). By permission of the British Library. (Maps C.7.c.20.)

8 George Lily, Britanniae Insulae (1546). By permission of the British Library. (Maps K.Top.5.1.)

9 Baptista Boazio, Irelande (1599). By permission of the British Library. (Maps C.2.cc.1.)

10 John Goghe, Hibernia (1567). Public Record Office, Kew. (MPF 68.)

11 John Speed, Kingdome of Irland (1611). By permission of the British Library. (Maps C.7.c.20.)

12 Richard Bartlett: map of Moyry Pass (1602/3). National Library of Ireland. (Ms. 2656.)

13 Richard Bartlett: map of Dungannon Castle and Tullaghoge (1602/3). National Library of Ireland. (Ms. 2656.)

14 Thomas Raven: the county of Londonderry (1622). Public Record Office Northern Ireland. (T/510/1.)

15 Thomas Raven: the Vintners' lands (1622). Public Record Office Northern Ireland. (T/510/1.)

16 Thomas Raven: the Vintners' buildings at Balleaghe (1622). Public Record Office Northern Ireland. (T/510/1.) 
This page intentionally left blank 


\section{Acknowledgements}

As this study crawled at snail's pace from enthusiastic early research through mid-thesis crisis towards its final form, I incurred many debts to teachers, colleagues and friends without whose generous help and expert advice I could never have completed this project. The book started life as a PhD thesis at Frankfurt University where in 1998 it was passed by Klaus Reichert, Eckhard Lobsien (both Frankfurt), and Manfred Pfister (Berlin). In the early stages, many people read hopelessly inadequate draft chapters and kept a straight face; thanks are due to Catarina Albano, Tom Healy, Gesa Mackenthun, Philip Orr, Quentin Skinner and the members of the Frankfurt Early Modern Research Group in the academic year 1994/5: Ina Habermann, Christian Schmitt, Susanne Scholz and Peter Sillem. To Gesa I am indebted in more ways than she may realize; without the example of her unfailing enthusiasm and down-to-earth approach to academic life I may never have had the courage to get started on this project. I am particularly grateful to those who went through the ordeal of reading the typescript in full: Andrew Gordon, Ina Habermann, David Matthews and Andrew McRae. All offered valuable criticism, helped me improve my English, and saved me from numerous blunders. David made sure that food for thought did not remain a hungry metaphor, both in London and France. Special thanks must go to Andrew Gordon who listened patiently when ideas were raw and who proved an ingenious partner in running a conference; I would like to thank him and all the speakers and attendants at our 1997 Paper Landscapes conference in London for making that event such a rare academic treat. Many other people have given generously of their time and experience in discussions and informal conversations; I would like to thank especially the late Francis Barker, Victoria von Flemming, Anne Fogarty, John Gillies, Richard Helgerson, Alf Mentzer, Andrew Murphy, Manfred Pfister, Kurt Tetzeli and the members of the London Renaissance Seminar. I am grateful to Charmian Hearne for her initial interest in the project and to Eleanor Birne and Anne Rafique for seeing the typescript through the press. Earlier versions of several chapters were first read as conference papers to audiences in Vienna, Reading, Southampton, Dresden, Weimar, Dublin, Mainz and Frankfurt; I am grateful to everybody who offered helpful criticism on these occasions. Needless to say, since my stubbornness kept me from accepting all the 
good advice I was offered, any errors that remain are entirely my own responsibility.

Portions of several chapters have already appeared in print. I am grateful to the editors of the Journal for the Study of British Cultures, the Irish University Review and Early Modern Literary Studies for allowing me to re-use material, all of which appears here in revised form. A version of Chapter 8 is to appear in Literature, Mapping, and the Politics of Space in Early Modern Britain, edited by Andrew Gordon and myself. Permissions to reproduce illustrations have been granted by the British Library (Figures 2.1, 2.2, 2.3, 2.4 and 8.1; Plates 4, 5, 6, 7, 8, 9 and 11), the Stadt- und Universitätsbibliothek Frankfurt am Main (Figures 1.1, 1.2, 1.4, 1.5, 1.6 and 1.7; Plates 2 and 3), the Deputy Keeper of Records, Public Record Office of Northern Ireland (Plates 14, 15 and 16), the Council of Trustees, National Library of Ireland (Plates 12 and 13), the Städelsches Kunstinstitut, Frankfurt (Plate 1), the Public Record Office, Kew (Plate 10), and the Senckenbergische Bibliothek, Frankfurt (Figure 1.3). Shelf-marks are quoted in the list of illustrations.

This is a book on space which has benefited immensely from the academic, social and institutional spaces in which it was researched and written, reading rooms in English, Irish and German libraries, flats in London, Frankfurt, Munich and Dortmund, and university departments in England and Germany. One social space has been more stimulating than all the others, the old North Library in the British Museum, an exceptionally fruitful academic environment that has now sadly vanished forever. Laptop Alley is sorely missed by all its former residents. For the academic year 1995/6 I was granted a scholarship by the German Academic Exchange Service (DAAD) which enabled me to spend a year at Birkbeck College, University of London. This visit proved crucial for the development of my work, and I would like to thank the DAAD, Birkbeck College, and especially Tom Healy for having made it possible, as well as my former colleagues at the Frankfurt English department for granting me a year's leave of absence. My current colleagues in Dortmund have all been exceptional in their support and encouragement, especially Jürgen Kramer. The greatest debt of all, both academic and personal, is owed to Ina Habermann, my most critical, encouraging and inspiring reader. 